\title{
An Error Analysis of Students' Difficulties in Differential Calculus
}

\author{
Meiliasari ${ }^{1}$, Dwi Antari Wijayanti ${ }^{2 *}$, Laely Astafiani Azima ${ }^{3}$ \\ ${ }_{1,2,3}$ Universitas Negeri Jakarta \\ *dwi-antari@unj.ac.id
}

Received: November 2020; Accepted: December 2020; Published: January 2021

\begin{abstract}
This study aims to describe the types of mistake and causes of the XI grade students of SMA Negeri 31 Jakarta TP. 2019/2020 made a mistake in solving the problem of an algebraic function derivative application. The method of this research is a qualitative descriptive study. The data was obtained by conducting tests and interview online. The respondents were drawn from 6 XI class in SMA Negeri 31 Jakarta. Each student's work was analyzed to describe the types of mistakes using the Newman analysis procedure, then an interview was conducted to describe the factors that caused students to make mistakes. Based on the results of the study, it can be concluded that the types of mistakes found when students solve problems in the application of algebraic function derivatives are 1) reading mistakes, that is, incorrectly writing the functions listed in the questions, 2) mistakes in understanding, in the form of misinterpreting what is known and asked about, 3) transformation mistakes, in the form of students' inability to choose procedures to solve problems appropriately, 4) process skill mistakes, in the form of incomplete student work, miscalculation, 5) conditioning mistakes, in the form of students' inability to show the final answer. The contributing factors are that students do not understand the derivative application material of algebraic functions, students are in a hurry to solve the problems, different types of questions given are different from the questions exemplified by the teacher, and rarely make conclusions at the end of the answer.
\end{abstract}

Keywords: analysis of mistakes, newman procedure, application of derivative algebraic functions.

How to Cite: Meiliasari, Wijayanti, D. A., \& Azima, L. A. (2021). An Error Analysis of Students' Difficulties in Differential Calculus. Journal of Medives: Journal of Mathematics Education IKIP Veteran Semarang, 5(1), 48-60. 


\section{PENDAHULUAN}

Kemampuan pemecahan masalah merupakan salah satu tujuan yang harus dicapai siswa dalam pembelajaran matematika. Menurut Burchartz dan Stein (dalam Yazgan, 2015), pemecahan masalah memiliki peran penting dalam matematika karena semua hal dalam matematika menuntut adanya pemecahan masalah. Hal ini sejalan dengan Uno (2011) yang menyatakan bahwa matematika merupakan suatu bidang ilmu yang memiliki unsur-unsur, yaitu logika dan intuisi, analisis dan konstruksi, generalitas dan individualitas; mempunyai cabang-cabang antara lain aritmatika, aljabar, geometri, dan analisis; serta memiliki peran sebagai alat berpikir, berkomunikasi, dan alat untuk memecahkan masalah berbagai persoalan praktis. Kedua pernyataan tersebut mengindikasi bahwa matematika merupakan bidang studi yang sangat erat kaitannya dengan aktivitas pemecahan masalah.

Berdasarkan data Puspendik Kemendikbud (2019), UN Matematika SMA/MA Jurusan IPA, IPS, dan Bahasa di DKI Jakarta tahun 2019 memiliki ratarata paling rendah di antara mata pelajaran lain. Pada jurusan IPA rata-rata UN Matematika di DKI Jakarta tahun 2019 sebesar 52,45. Nilai rata-rata UN matematika di DKI Jakarta tahun 2019 paling kecil diantara ketiga jurusan diperoleh Jurusan IPS sebesar 44,48. Sedangkan pada jurusan Bahasa rata-rata UN Matematika di DKI Jakarta tahun 2019 adalah 49,60. Bahkan untuk nilai daya serap pada indikator yang menuntut siswa untuk menyelesaikan permasalahan kontekstual yang berkaitan dengan
Turunan Fungsi Aljabar hanya sebesar 10,05 pada Jurusan IPA, 3,20 pada Jurusan IPS, tetapi pada Jurusan Bahasa tidak diujikan untuk indikator tersebut (Puspendik Kemendikbud, 2019). Hal ini menujukkan bahwa siswa masih mengalami kesulitan dalam menyelesaikan masalah kontekstual, khususnya pada Turunan Fungsi Aljabar. Selain itu, hanya sedikit siswa yang menjawab benar dalam menyelesaikan permasalahan kontekstual.

Menurut Widarti (2013), permasalahan kontekstual adalah suatu masalah yang berkaitan dengan kehidupan seharihari. Biasanya permasalahan kontekstual dapat berbentuk soal cerita yang mengaitkan matematika dengan masalah dalam kehidupan sehari-hari. Soal cerita cenderung lebih sulit daripada soal yang hanya berisi bilangan. Hal ini dikarenakan dalam menyelesaikan masalah yang berbentuk cerita, siswa harus melewati beberapa tahap, selain menghitung. Beberapa tahapnya adalah siswa harus memahami isi soal tersebut, mengetahui objek matematika apa yang harus diselesaikan, membuat objek tersebut menjadi model matematika, memilih operasi hitung yang tepat untuk menyelesaikannya, dan menarik kesimpulan.

Salah satu pokok bahasan yang baru dipelajari siswa di tingkat SMA adalah materi turunan fungsi. Dimana materi ini dipelajari pada mata pelajaran matematika wajib SMA kelas XI hanya terbatas di turunan fungsi aljabar. Konsep turunan fungsi yang abstrak dapat menyebabkan siswa mengalami kesulitan dalam mempelajarinya. Hal ini akan mempengaruhi siswa dalam menyelesaikan masalah yang berkaitan 
dengan materi turunan fungsi sehingga dapat membuat siswa melakukan kesalahan-kesalahan yang tidak seharusnya.

Dalam penelitian Asih, Rosita, dan Tonah (2018) menunjukkan bahwa siswa kesulitan dalam mengidentifikasi bentuk limit tak tentu. Jika hasil substitusi titik limit ke dalam fungsi adalah $\frac{0}{0}$ (bentuk tak tentu), maka hasil limit dapat ditentukan dengan menggunakan metode pemfaktoran atau perkalian sekawan. Namun, jika fungsinya sulit atau tidak dapat difaktorkan, maka akan lebih mudah menggunakan aturan L'Hospital yang terdapat turunan di dalamnya. Selanjutnya, siswa mengalami kesulitan dalam mengubah soal cerita ke dalam model matematika yang tepat dan mengaitkan permasalahan dengan konsep lain yang berkaitan.

Berdasarkan hasil penelitian Apriliyanto (2019), kesalahan yang paling sering dilakukan siswa dalam menyelesaikan soal tentang turunan fungsi aljabar adalah kesalahan konsep, dengan persentase 42,5\%. Daniel, Naisunis, dan Taneo (2018) menyatakan bahwa kesalahan konsep dapat disebabkan oleh siswa yang tidak memahami apa yang dimaksud soal. Selain kesalahan konsep, siswa juga melakukan kesalahan fakta (27,5\%), kesalahan prinsip (7,5\%), dan kesalahan operasi $(22,5 \%)$. Kesalahan yang dilakukan siswa dapat mengidentifikasi sejauh mana pemahaman siswa pada materi tersebut. Kesalahan dalam menyelesaikan masalah akan mempengaruhi hasil belajar yang diperoleh siswa. Oleh karena itu, agar kesalahan tidak terulang serta dapat memperbaiki hasil belajar siswa maka perlu dilakukan analisis kesalahan pada pekerjaan siswa. Melalui analisis kesalahan akan didapatkan bentuk dan penyebab kesalahan siswa, sehingga guru dapat memberikan bantuan kepada siswa dan sebagai bahan pertimbangan dalam kegiatan pembelajaran. Setelah itu, diharapkan dapat memperbaiki hasil belajar siswa.

Berdasarkan penjelasan di atas, peneliti telah melakukan penelitian dengan fokus sebagai berikut. (1) Bagaimana kesalahan yang siswa lakukan dalam memecahkan masalah yang berkaitan dengan aplikasi turunan fungsi aljabar? (2) Faktor apa saja yang menyebabkan siswa melakukan kesalahan dalam memecahkan masalah yang berkaitan dengan aplikasi turunan fungsi aljabar? Adapun tujuan dari penelitian ini adalah mendeskripsikan kesalahan yang dilakukan siswa dan faktor penyebabnya dalam memecahkan masalah yang berkaitan dengan aplikasi turunan fungsi aljabar.

\section{METODE PENELITIAN}

Metode penelitian yang digunakan adalah penelitian deskriptif dengan pendekatan kualitatif. Penelitian ini dilaksanakan di kelas XI SMA Negeri 31 Jakarta dan mengambil responden sebanyak 6 kelas dari 3 jurusan, yaitu IPA, IPS, dan Bahasa. Penelitian dilaksanakan dari bulan April sampai Juni 2020. Pengumpulan data yang dilakukan dalam penelitian ini adalah tes kemampuan pemecahan masalah dan wawancara secara online. Sedangkan wawancara semi terstruktur dilakukan secara individual kepada 14 siswa yang menjadi narasumber. Wawancara ini 
bertujuan untuk mengetahui faktorfaktor penyebab siswa melakukan kesalahan dalam memecahkan masalah yang berkaitan dengan aplikasi turunan fungsi aljabar. Pemilihan responden penelitian dan siswa yang diwawancara menggunakan purposive sampling. Instrumen penelitian ini adalah soal uraian tes kemampuan pemecahan masalah pada materi aplikasi turunan dan pedoman wawancara semiterstrukstur.

\section{HASIL DAN PEMBAHASAN Kesalahan yang Dilakukan Siswa}

Berdasarkan analisis hasil tes siswa dengan menggunakan prosedur Newman, dapat diketahui kesalahankesalahan yang dilakukan oleh siswa dalam memecahkan masalah aplikasi turunan fungsi aljabar. Hasil analisis data disajikan pada Tabel 1. Setiap kesalahan yang telah dikategorikan jenisnya berdasarkan analisis kesalahan Newman, kemudian dianalisis lebih mendalam. Hal ini bertujuan untuk mengetahui tipe kesalahan yang terjadi pada kesalahan membaca, kesalahan memahami, kesalahan transformasi, kesalahan keterampilan proses, dan kesalahan pengkondisian.

\begin{tabular}{|c|c|c|c|c|c|}
\hline \multirow{2}{*}{ Jenis Kesalahan } & \multicolumn{5}{|c|}{ Nomor Soal } \\
\hline & 1 & 2 & 3 & 4 & 5 \\
\hline $\begin{array}{c}\text { Kesalahan } \\
\text { membaca }\end{array}$ & 4,1 & 23,7 & 14,9 & 53,1 & 4,1 \\
\hline $\begin{array}{l}\text { Kesalahan } \\
\text { memahami }\end{array}$ & 21,9 & 2,2 & 3,3 & 65,9 & 6,6 \\
\hline $\begin{array}{l}\text { Kesalahan } \\
\text { transformasi }\end{array}$ & 5,6 & 6,5 & 39,8 & 27,8 & 20,7 \\
\hline $\begin{array}{l}\text { Kesalahan kete- } \\
\text { rampilan proses }\end{array}$ & 20,1 & 8,3 & 26,9 & 22,5 & 22,1 \\
\hline $\begin{array}{l}\text { Kesalahan peng- } \\
\text { kondisian }\end{array}$ & 24,4 & 2,3 & 28,7 & 23,6 & 20,9 \\
\hline
\end{tabular}

Berikut ini uraian dari setiap jenis kesalahan berdasarkan analisis kesalahan Newman.

\section{Kesalahan Membaca (Reading)}

Kesalahan membaca, yaitu kesalahan siswa dalam membaca soal matematika yang diberikan serta mengidentifikasi kalimat dan simbol matematika yang digunakan. Jenis kesalahan ini dapat menghambat siswa untuk melanjutkan proses pengerjaannya lebih jauh. Kesalahan yang dilakukan siswa pada jenis ini, antara lain salah menuliskan fungsi yang diberikan oleh soal dan tidak menuliskan informasi penting yang tertera pada soal.

Kesalahan membaca paling banyak terjadi pada soal Nomor 4 yang berbentuk soal cerita. Banyak siswa yang tidak mengilustrasikan informasi yang terdapat pada soal dalam bentuk gambar. Hal ini dapat dikarenakan siswa yang tidak mampu menangkap informasi tersebut dengan baik atau siswa tidak terbiasa menuliskannya. Sebagian siswa terkecoh dengan salah satu kalimat dalam soal tersebut yang berbunyi "pada keempat titik sudutnya dibuat potongan berbentuk persegi dengan ukuran yang sama". Sebagai ilustrasi, pada Gambar 1 menunjukkan bahwa siswa menginterpretasikan keempat potongan persegi yang dibuat di titik sudut berukuran sama dengan sisa persegi lainnya, sehingga sisi karton masing-masing dibagi 3 dan menghasilkan pesegi kecil yang berukuran $6 \mathrm{~cm}$. Dari panjang sisi tersebut, siswa menghitung volume kotak terbesar menggunakan rumus volume kubus dengan sisi $6 \mathrm{~cm}$. 


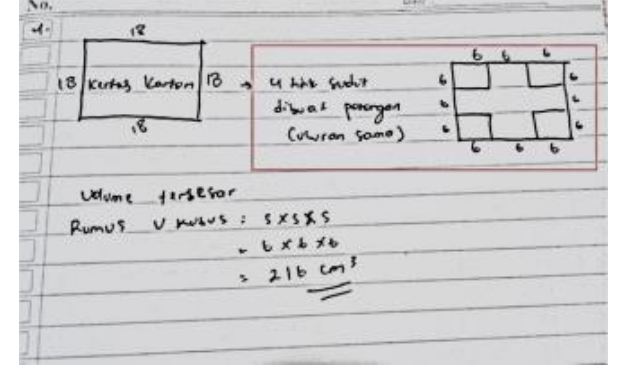

Gambar 1. Contoh Kesalahan Membaca Soal 4

Selain itu, pada soal Nomor 3 tentang limit L'Hospital seperti pada Tabel 1, beberapa siswa melakukan kesalahan dalam menuliskan fungsi yang tertera pada soal. Soal tersebut mengharuskan siswa untuk menentukan nilai dari variabel yang belum diketahui. Beberapa siswa tidak menuliskan $\left(x^{3}-8\right)$, melainkan menulis $(x-2)$ sebagai penyebut. Gambar 2 merupakan contoh kesalahan siswa dalam menuliskan penyebut pada soal Nomor 3 .

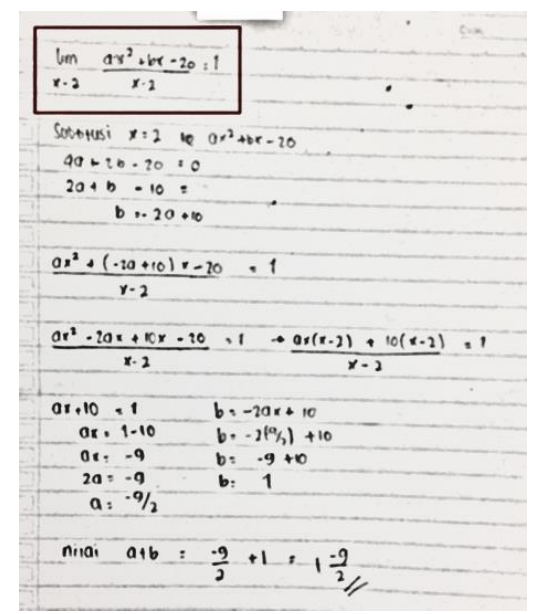

Gambar 2. Contoh Kesalahan Membaca Soal 3

Faktor penyebabnya adalah siswa kurang menguasai materi yang terkandung pada soal aplikasi turunan fungsi aljabar, kurang teliti dalam membaca soal, ataupun tergesa-gesa saat akan mengerjakannya. Hal ini sejalan dengan pendapat yang dikemukakan oleh Abdullah, Abidin, dan Ali (2015) bahwa siswa yang tidak mengerti materi secara keseluruhan dapat menyebabkan siswa melakukan kesalahan. Selain itu, hasil penelitian ini menunjukkan bahwa kesalahan membaca dapat disebabkan oleh ketidakpahaman siswa terhadap materi, kurang teliti dalam membaca soal, serta tergesa-gesa saat akan mengerjakannya.

Hal ini menambahkan penelitian sebelumnya yang menjelaskan bahwa kesalahan membaca disebabkan oleh kurangnya pengetahuan siswa mengenai simbol-simbol matematika dan belum lancarnya siswa dalam membaca (Humaerah, 2017).

\section{Kesalahan Memahami (Comprehension)}

Kesalahan memahami adalah kesalahan siswa dalam memahami dan menjelaskan maksud dari masalah matematika yang diberikan. Jenis kesalahan ini terlihat dari siswa yang salah menafsirkan apa yang diberikan dan diminta oleh soal. Salah dalam memahami soal dapat menyebabkan siswa memilih prosedur yang kurang tepat untuk memecahkannya. Kesalahan memahami paling banyak terjadi pada soal Nomor 4 dengan persentase 29,7\% dari siswa yang mengikuti tes.

Berdasarkan Gambar 3 dapat ditemukan bahwa siswa memahami apa yang diminta oleh soal, yaitu volume kotak terbesar yang dapat dibuat. Namun, banyak siswa yang tidak memahami apa yang diketahui pada soal. Siswa menafsirkan kalimat "pada keempat titik sudut kertas karton dibuat potongan persegi dengan ukuran yang sama" sebagai kertas karton yang panjang sisinya masing-masing dibagi 
menjadi tiga bagian, sehingga menghasilkan sebuah kubus yang memiliki sisi sebesar $6 \mathrm{~cm}$. Oleh karena itu, siswa menghitung volume kotak terbesar menggunakan rumus volume kubus.

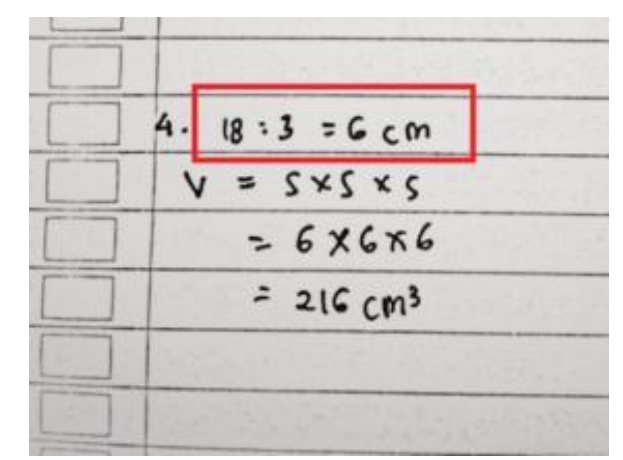

Gambar 3. Contoh Kesalahan Memahami Soal 4

Pada jurusan IPS, kesalahan memahami paling banyak terjadi pada soal Nomor 5 dimana siswa diminta untuk menganalisis dan menggambar kurva dari suatu fungsi. Banyak siswa yang tidak memahami apa yang diminta soal, sehingga siswa hanya menuliskan fungsinya saja pada lembar jawaban mereka. Sementara itu, seluruh siswa jurusan Bahasa tidak memahami maksud soal Nomor 2. Padahal soal tersebut sejenis dengan soal yang guru ajarkan di kelas, yang membedakan hanyalah gambar yang seharusnya dapat membantu siswa dalam menyelesaikan soal tersebut.

Penyebab siswa melakukan kesalahan memahami yang ditemukan dalam penelitian ini adalah siswa kurang menguasai materi yang terkandung dalam soal, siswa tidak mengerti apa yang diminta oleh soal, tidak tertarik dengan matematika, dan bingung menuliskan kembali apa yang dimaksud oleh soal. Hal ini sejalan dengan penelitian Abdullah dkk. (2015) dan
Isnaeni (2016) yang menyatakan bahwa salah satu penyebab siswa mengalami kesalahan memahami adalah ketidakpahaman siswa terhadap materi secara keseluruhan. Siswa tidak memahami bahwa konsep turunan digunakan untuk menyelesaikan masalah. Humaerah (2017), Siregar (2018), Syahruddin (2018), dan Lailiyah (2019) juga menyatakan bahwa siswa kebingungan dalam menuliskan hal yang diketahui dan ditanyakan dalam soal. Di lain sisi, hasil penelitian ini menambahkan penelitian Rohmah \& Sutiarso (2018) yang menjelaskan penyebab siswa melakukan kesalahan memahami hanyalah karena siswa tidak mampu menangkap informasi dengan baik.

\section{Kesalahan Transformasi (Transformation)}

Kesalahan transformasi adalah kesalahan siswa dalam memilih operasi dan prosedur yang digunakan untuk menyelesaikan masalah matematika. Jenis kesalahan ini terlihat dari siswa yang tidak mampu memilih ataupun salah menggunakan prosedur dan operasi untuk menyelesaikan masalah. Kesalahan transformasi paling banyak terjadi pada soal Nomor 3 tentang limit L'Hospital. Banyak siswa yang memilih untuk menggunakan metode substitusi dalam menyelesaikan soal tersebut.

Walaupun bisa menggunakan metode tersebut, tetapi tidak sesuai dengan materi yang terkandung dalam tes yang diberikan. Selain itu, mayoritas siswa yang menggunakan metode substitusi melakukan kesalahan dalam proses penyelesaian, sehingga hasil akhir yang diperoleh kurang tepat seperti diilustrasikan pada Gambar 4. 


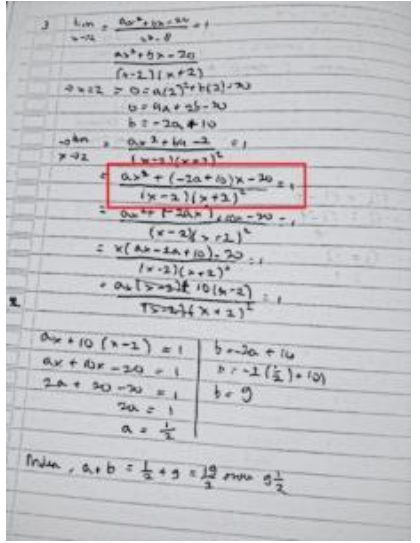

Gambar 4. Contoh Kesalahan Transformasi Soal 3

Sementara itu, semua siswa jurusan Bahasa mengalami kesalahan transformasi ketika menyelesaikan soal Nomor 2, 3, dan 5. Penyebab mereka melakukan kesalahan pada soal Nomor 2 adalah karena siswa tidak mampu memahami soal dengan baik, sehingga membuat siswa tidak dapat memilih prosedur untuk menyelesaikan soal tersebut. Di sisi lain, siswa sudah menguasai materi mengenai persamaan garis singgung dalam pengaplikasian turunan fungsi aljabar. Hal ini terlihat dari bagaimana respons siswa ketika guru mengajarkan materi tersebut di kelas.

Demikian pula dengan soal Nomor 5, banyak siswa tidak memahami apa yang diminta oleh soal. Hanya 3 orang siswa dari jurusan Bahasa yang mampu memahami soal Nomor 5, tetapi prosedur penyelesaian yang mereka pilih pun kurang tepat. Misalnya, ada siswa yang menggunakan rumus titik puncak pada fungsi kuadrat untuk menentukan titik puncak pada fungsi berpangkat 3 , seperti pada Gambar 5.

Faktor penyebab kesalahan transformasi yang ditemukan dalam penelitian ini berupa kepanikan siswa karena waktu yang tersisa tidak banyak serta siswa belum pernah mengerjakan soal sejenis dapat menambahkan penelitian Rohmah dan Sutiarso (2018) yang menjelaskan bahwa faktor penyebab siswa melakukan kesalahan transformasi adalah ketidakmampuan siswa dalam menyerap informasi dengan benar, siswa tidak mengerti materi sepenuhnya, dan kecerobohan siswa saat mengerjakan soal.

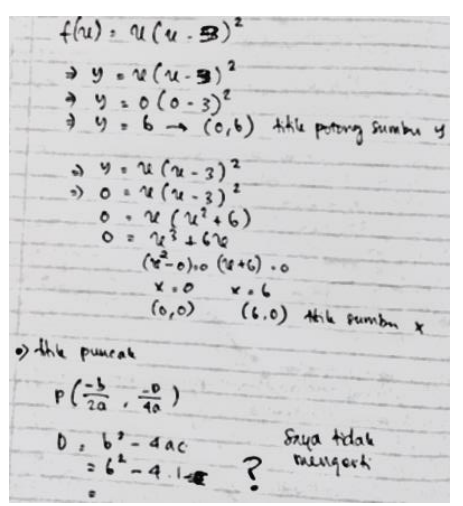

Gambar 5. Contoh Kesalahan Transformasi Soal 5

Hasil penelitian ini juga sejalan dengan hasil penelitian Syahruddin (2018) dan Siregar (2018) yang menyatakan bahwa penyebab kesalahan transformasi adalah ketidakpahaman siswa dengan metode penyelesaian yang digunakan, siswa tidak mengetahui metode penyelesaian yang benar, dan siswa tergesa-gesa dalam menyelesaikan soal karena waktu yang hampir habis.

Menurut Abdullah dkk. (2015), kurangnya pengalaman siswa dalam memecahkan masalah dapat menjadi penyebab siswa melakukan kesalahan. Siswa kurang berlatih dengan variasi soal yang lebih banyak, terutama soal cerita berbentuk narasi tanpa ilustrasi dan variasi soal yang lebih kompleks, sehingga siswa sering bingung bagai- 
mana menyelesaikan soal. Siswa tidak terbiasa memikirkan penyelesaian alternatif untuk masalah yang berbeda dari contoh yang dipelajari, mereka sering dilatih untuk mengikuti instruksi, dan jarang didukung oleh pembenaran konseptual.

\section{Kesalahan Keterampilan Proses (Process Skill)}

Kesalahan keterampilan proses, yaitu kesalahan siswa dalam memproses operasi dan prosedur yang telah dipilih untuk menyelesaikan masalah matematika yang diberikan. Kesalahan ini dapat terlihat dari pengerjaan prosedur yang tidak lengkap, kesalahan dalam menghitung, maupun adanya langkah yang tidak sesuai dengan prosedur yang siswa pilih. Jenis kesalahan ini paling banyak terjadi jika dibandingkan dengan jenis kesalahan lainnya pada semua Nomor soal.

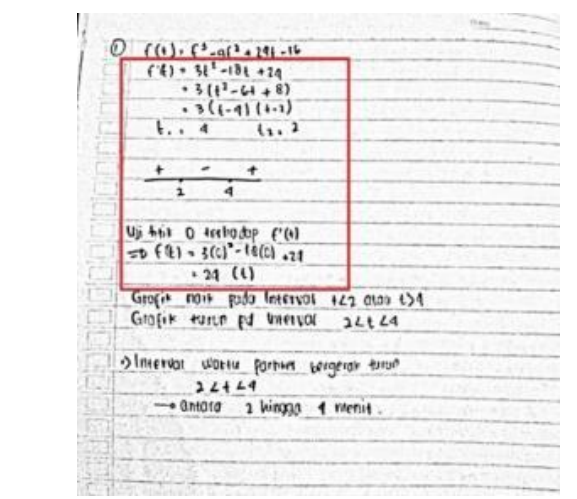

Gambar 6. Contoh Kesalahan Keterampilan Proses Soal 1

Pada soal Nomor 1, siswa diminta untuk menentukan interval waktu ketika kurva bergerak turun. Banyak siswa yang tidak menuliskan syarat suatu fungsi turun, tanda pertidaksamaan, dan tidak membuat garis bilangan. Kesalahan seperti itu dapat menyebabkan beberapa siswa keliru dalam menyimpulkan jawaban akhir. Walaupun begitu, tidak sedikit siswa menyimpulkan dengan tepat, seperti pada Gambar 6.

Pada soal Nomor 2, kesalahan yang banyak terjadi dikarenakan siswa tidak memahami apa yang dimaksud oleh soal, sehingga siswa tidak mengerjakannya sama sekali. Selain itu, beberapa siswa menuliskan tahap pengerjaan secara tidak lengkap. Tahap pengerjaan yang harus dilalui siswa adalah mencari gradien garis singgung dan persamaan garis singgung, menentukan titik potong garis singgung dengan sumbu $x$ dan sumbu $y$, serta menghitung luas segitiga yang terbentuk dari garis singgung kurva, sumbu $x$, dan sumbu $y$. Namun, terdapat siswa yang menuliskan tahap menghitung luas segitiganya saja, tanpa tahap sebelumnya, seperti pada Gambar 7.

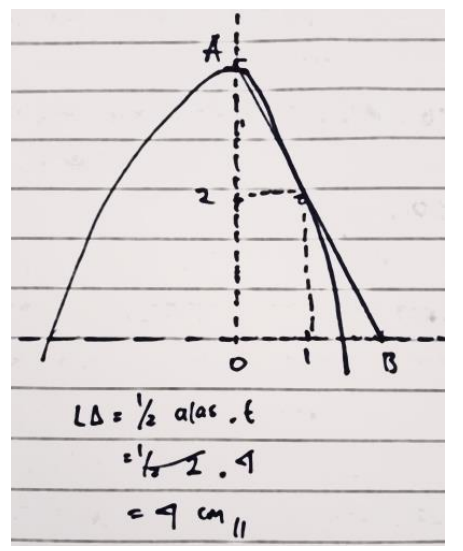

Gambar 7. Contoh Kesalahan Keterampilan Proses Soal 2

Sementara itu, pada soal Nomor 3 didominasi oleh siswa yang menggunakan metode substitusi. Siswa melakukan berbagai jenis kesalahan dalam mengoperasikan aljabar, sehingga menghasilkan nilai jawaban akhir yang bervariasi. Namun, terdapat juga siswa 
yang mengerjakan dengan limit L'Hospital, tetapi mengalami kesalahan perhitungan ataupun tidak menuliskan langkah pengerjaannya secara lengkap.

Sedangkan pada soal Nomor 4, sebagian besar siswa melakukan kesalahan jenis ini dikarenakan mereka mengalami tiga jenis kesalahan sebelumnya, yaitu kesalahan membaca, kesalahan memahami, dan kesalahan transformasi. Siswa yang tidak mampu menangkap informasi yang terdapat pada soal secara otomatis tidak dapat menafsirkan apa yang diberikan dan diminta oleh soal, sehingga menyebabkan siswa memilih prosedur yang tidak tepat serta salah dalam mengerjakannya.

Soal Nomor 5 membutuhkan langkah pengerjaan yang cukup panjang dibanding dengan 4 soal sebelumnya. Siswa harus menentukan interval fungsi ketika naik dan turun, titik optimum yang dicapai oleh fungsi, titik potong kurva terhadap sumbu $x$ dan sumbu $y$, serta beberapa titik sembarang sebelum siswa menggambar kurva. Namun, sebagian siswa hanya menentukan interval fungsi ketika naik dan turun, kemudian langsung menggambar kurva, seperti pada Gambar 8.

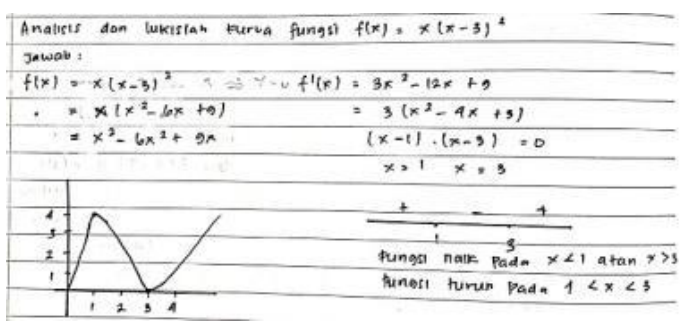

Gambar 8. Contoh Kesalahan Keterampilan Proses Soal 5

Faktor penyebab siswa melakukan kesalahan jenis ini adalah kurang teliti dalam menghitung, tidak terbiasa menu- liskan syarat suatu fungsi turun, lupa menuliskan tanda pertidaksamaannya, terburu-buru, dan model soal yang berbeda dengan soal yang guru contohkan. Ketidaktelitian siswa dalam menghitung sudah banyak menjadi salah satu faktor yang mengakibatkan siswa melakukan kesalahan keterampilan proses, seperti pada penelitian yang dilakukan oleh (Humaerah, 2017; Rohmah dan Sutiarso, 2018; Siregar, 2018; Syahruddin, 2018; Lailiyah, 2019; Safitri dkk., 2019). Penelitian ini menambahkan hasil penelitian dari Chusnul dkk. (2017) yang menuliskan bahwa kesalahan keterampilan proses terjadi ketika siswa dapat mengidentifikasi prosedur yang akan digunakan, tetapi tidak mengetahui langkah-langkah yang diperlukan untuk melakukan prosedur tersebut dengan sempurna atau siswa kurang teliti dalam menjalankan prosedur tersebut.

\section{Kesalahan Pengkondisian (Encoding)}

Kesalahan pengkondisian adalah kesalahan siswa dalam menunjukkan jawaban akhir dari masalah matematika yang diberikan. Kesalahan ini dapat disebabkan oleh pemilihan prosedur yang digunakan ataupun proses perhitungan dengan prosedur yang telah dipilih kurang tepat. Jenis kesalahan ini paling banyak ditemukan pada soal Nomor 5, dimana siswa diminta untuk menggambar fungsi kurva yang tertera pada soal. Sebagian besar penyebabnya adalah tahap pengerjaan yang dituliskan kurang lengkap. Sementara itu, siswa jurusan IPA paling banyak melakukan kesalahan pengkondisian pada soal Nomor 3. Hal ini dikarenakan adanya 
kekeliruan siswa dalam memilih prosedur yang digunakan serta memproses prosedur yang telah dipilih, sehingga siswa salah dalam menentukan jawaban akhir.

Selain itu, sebanyak 85 siswa mengalami kesalahan pengkondisian pada soal Nomor 1. Kesalahan paling dominan terjadi karena siswa salah menuliskan variabel pada jawaban akhir. Variabel yang digunakan pada soal 1 adalah $t$, tetapi 40 siswa menuliskannya sebagai $x$ di jawaban akhir mereka, seperti terlihat pada Gambar 9.

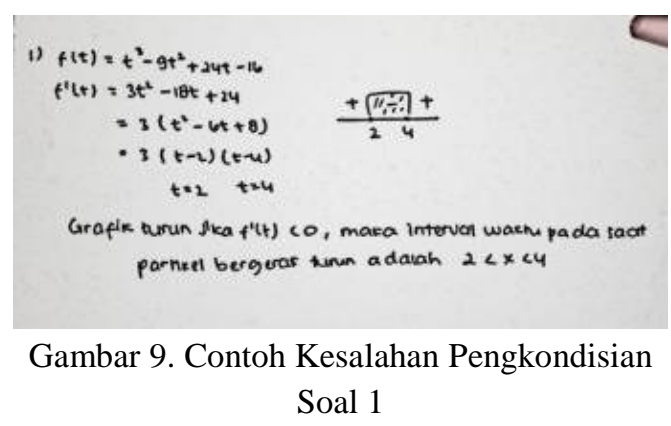

Fakor yang menyebabkan siswa melakukan kesalahan jenis ini adalah ketidakpahaman siswa mengenai bentuk dari kesimpulan itu sendiri dan jarang membuat kesimpulan sehingga sulit untuk membentuknya, seperti yang dikatakan dalam penelitian (Siregar, 2018). Adapun siswa yang salah menuliskan jawaban akhir seperti salah tanda pertidaksamaan dalam menentukan interval waktu, dapat disebabkan karena ketidakpahaman siswa terhadap apa yang diminta oleh soal. Menurut penelitian Humaerah (2017), Santoso dkk. (2017), Lailiyah (2019), salah satu penyebab terjadinya kesalahan dalam menuliskan jawaban akhir adalah siswa tidak memahami apa yang ditanyakan oleh soal. Selain itu, ada siswa yang salah menafsirkan materi, sehingga salah dalam menentukan jawaban akhir.

\section{Faktor Penyebab Kesalahan Siswa}

Secara keseluruhan, dapat dilihat bahwa semua siswa yang mengikuti tes melakukan kesalahan pada soal yang diberikan, meskipun tidak semua soal yang mereka kerjakan dilakukan secara salah. Faktor penyebab siswa melakukan kesalahan dapat diperoleh dari data hasil observasi dan wawancara. Berikut adalah hasil analisis data untuk faktor penyebab kesalahan siswa.

Pada saat wawancara, semua subjek penelitian dapat membaca soal dengan benar dan lengkap, namun terdapat beberapa siswa yang kesulitan dalam menangkap informasi yang terdapat pada soal ketika sudah membaca soal secara lengkap. Hal ini dikarenakan siswa kurang menguasai materi yang terkandung pada soal yang diberikan. Selain itu, beberapa siswa juga salah menuliskan fungsi yang tertera pada soal, karena siswa kurang teliti dalam membaca soal ataupun tergesa-gesa saat akan mengerjakannya.

Sebagian besar subjek penelitian yang diwawancara dapat menjelaskan apa yang dimaksud oleh soal. Akan tetapi, ada beberapa siswa yang kurang mampu memahami soal yang diberikan. Penyebabnya adalah siswa kurang menguasai materi yang terkandung dalam soal, siswa tidak mengerti apa yang diminta oleh soal, tidak tertarik dengan matematika, dan bingung menuliskan kembali apa yang dimaksud oleh soal.

Dari hasil observasi dan wawancara dengan salah satu siswa jurusan 
Bahasa, kelas tersebut sudah menguasai materi persamaan garis singgung ketika guru mengajarkannya di kelas. Namun, pada saat siswa diberikan soal Nomor 2 yang berkaitan dengan materi tersebut, tidak ada satupun siswa yang mampu menyelesaikannya. Hal ini dikarenakan siswa bingung dalam menentukan luas segitiga yang terdapat pada gambar yang tertera pada soal. Siswa tidak mengerti cara mencari persamaan garis singgungnya, karena model soal yang diberikan tidak ada di catatan miliknya. Dari hasil observasi, guru menjelaskan dan mengilustrasikan apa yang dimaksud dari persamaan garis singgung dengan gambar, tetapi soal-soal yang guru bahas di kelas tidak ada yang menyertakan gambar.

Tidak sedikit siswa yang memahami soal, tetapi salah dalam memilih prosedur yang mereka gunakan untuk menyelesaikannya. Beberapa faktor penyebabnya, antara lain lupa menggunakan metode penyelesaian yang seharusnya digunakan, tidak mengetahui metode yang seharusnya digunakan, belum pernah mengerjakan soal yang sejenis dengan soal yang diberikan, tidak mengerti bagaimana cara menjawabnya, dan panik karena waktu yang tersisa tidak banyak. Pada sesi wawancara siswa mengatakan bahwa ia tidak mengetahui cara mengerjakannya.

Semua subjek penelitian yang diwawancara melakukan kesalahan keterampilan proses. Kesalahan yang terjadi dapat berupa tidak mengerjakan hingga selesai, ada langkah penyelesaian yang kurang, maupun langkah penyelesaian yang tidak sesuai dengan prosedur yang dipilih. Faktor penyebab siswa melakukan kesalahan jenis ini adalah kurang teliti dalam menghitung, tidak terbiasa menuliskan syarat suatu fungsi turun, lupa menuliskan tanda pertidaksamaannya, terburu-buru, dan model soal yang berbeda dengan soal yang guru contohkan. Salah satu contohnya adalah siswa tidak terbiasa menuliskan syarat fungsi turun dan lupa menuliskan tanda pertidaksamaan.

Beberapa subjek penelitian bingung ketika ditanya mengenai kesimpulan dari soal yang diberikan. Faktanya, mereka sudah tepat menuliskan jawaban akhir yang diminta oleh soal pada lembar jawabannya. Hal ini disebabkan oleh ketidakpahaman siswa mengenai bentuk dari kesimpulan itu sendiri dan siswa jarang membuat kesimpulan sehingga sulit untuk membentuknya. Selain itu, terdapat siswa yang salah menuliskan jawaban akhir seperti salah tanda pertidaksamaan dalam menentukan interval waktu, dapat disebabkan karena ketidakpahaman siswa terhadap apa yang diminta oleh soal. Selain itu, ada siswa yang salah menafsirkan materi, sehingga salah dalam menentukan jawaban akhir.

\section{PENUTUP}

Berdasarkan hasil penelitian dapat disimpulkan bahwa jenis-jenis kesalahan yang ditemukan ketika siswa memecahkan masalah aplikasi turunan fungsi aljabar adalah sebagai berikut. 1) Kesalahan membaca berupa salah menuliskan fungsi yang tertera pada soal, 2) kesalahan memahami berupa salah menafsirkan apa yang diketahui dan diminta soal, 3) kesalahan transformasi berupa ketidakmampuan siswa dalam memilih prosedur untuk 
memecahkan masalah dengan tepat, 4) kesalahan keterampilan proses berupa ketidaklengkapan pekerjaan siswa, salah menghitung, dan 5) kesalahan pengkondisian berupa ketidakmampuan siswa menun-jukkan jawaban akhir. Adapun faktor penyebabnya adalah siswa kurang menguasai materi aplikasi turunan fungsi aljabar, kecerobohan siswa, terburu-buru dalam memecahkan masalah, model soal berbeda dengan soal yang dicontohkan guru, dan jarang membuat kesimpulan di akhir jawaban.

\section{DAFTAR PUSTAKA}

(Ken) Clements, M. A. (1980). Analyzing children's errors on written mathematical tasks. Educational Studies in Mathematics, 11(1), 1-21.

Abdullah, A. H., Abidin, N. L. Z., \& Ali, M. (2015). Analysis of students' errors in solving Higher Order Thinking Skills (HOTS) problems for the topic of fraction. Asian Social Science, 11(21), 133.

Apriliyanto, B. (2019). Analisis kesalahan siswa dalam pemecahan masalah turunan fungsi aljabar. Jurnal Komunikasi Pendidikan, 3(2), 117-125.

Asih, K. S., Rosita, C. D., \& Tonah, T. (2018). Analisis learning obstacles pada pokok bahasan aplikasi turunan pada siswa kelas XI SMA. Prosiding Seminar Nasional Matematika Dan Pendidikan Matematika (SNMPM), 2(1), 211221.

Chusnul, R., Mardiyana, \& Retno, D. (2017). Errors analysis of problem solving using the newman stage after applying cooperative learning of TTW type. International
Conference and Workshop on Mathematical Analysis and Its Applications (ICWOMAA 2017), 1-7. Surakarta: AIP Publishing.

Daniel, F., Naisunis, Y. P., \& Taneo, P. N. L. (2018). Analisis kesalahan mahasiswa dalam pemecahan masalah pada mata kuliah persamaaan diferensial. Edumatica: Jurnal Pendidikan Matematika, 8(2), 107-119.

Gunawan, A. (2016). Analisis kesalahan dalam menyelesaikan soal cerita pada mata pelajaran matematika siswa kelas V SDN 59 Kota Bengkulu. Jurnal PGSD: Jurnal Ilmiah Pendidikan Guru Sekolah Dasar, 9(2), 216-225.

Humaerah, S. R. (2017). Analisis kesalahan siswa dalam menyelesaikan soal-soal pada materi geometri dengan prosedur Newman kelas VIII MTs Muhammadiyah Tanetea Kabupaten Jeneponto. Skripsi. UIN Alauddin Makassar.

Isnaeni, L. (2016). Analisis kesalahan siswa dalam menyelesaikan masalah aplikasi turunan fungsi ditinjau dari kemampuan awal siswa kelas XI IPA SMA Negeri 6 Surakarta. Skripsi, tidak dipublikasi. Universitas Sebelas Maret.

Kudsiyah, S. M., Novarina, E., \& Lukman, H. S. (2017). Faktorfaktor yang mempengaruhi kemampuan pemecahan masalah matematika kelas $\mathrm{X}$ di SMA Negeri 2 Kota Sukabumi. Seminar Nasional 2017, 110-117. Retrieved from http://eprints.ummi.ac.id/202/3/16

Lailiyah, R. A. (2019). Analisis kesalahan siswa dalam 
menyelesaikan soal cerita operasi aljabar berdasarkan tahapan Newman Error Analysis (NEA) kelas VII B SMP Islam Gandusari Trenggalek. Skripsi. Institut Agama Islam Negeri Tulungagung.

Lester Jr, F. K. (2003). From problem solving to modeling: the evolution of thinking about research on complex mathematical activity. Beyond Constructivism: Models and Modeling Perspectives on Mathematical Problem Solving, Learning, and Teaching.

Puspendik Kemendikbud. (2019). Laporan hasil ujian nasional. Diakses pada 5 November 2019, dari https://puspendik.kemdikbud.go.i d/hasil-un/

Rohmah, M., \& Sutiarso, S. (2018). Analysis problem solving in mathematical using theory Newman. EURASIA Journal of Mathematics, Science and Technology Education, 14(2), 671-681.

Safitri, F. A., Sugiarti, T., \& Hutama, F. S. (2019). Analisis kesalahan siswa dalam menyelesaikan soal cerita bangun datar berdasarkan Newman's Error Analysis (NEA). Jurnal Profesi Keguruan, 5(1), 42-49.

Santoso, D. A., A., F., \& Ulum, B. (2017). Error analysis of students working about word problem of linear program with NEA procedure. Journal of Physics: Conference Series, 855. Surakarta:
IOP Publishing.

Siregar, D. P. (2018). Analisis kesalahan siswa dalam menyelesaikan soal cerita matematika berdasarkan prosedur Newman di SMP Muhammadiyah 02 Medan T.P 2017/2018. Skripsi. Universitas Muhammadiyah Sumatera Utara.

Syahruddin. (2018). Analisis kesalahan siswa dalam menyelesaikan soal cerita operasi hitung bilangan bulat pada siswa kelas VII SMP Negeri 21 Makassar. Skripsi. Universitas Negeri Makassar.

Uno, H. B. (2011). Teori motivasi \& pengukurannya: kajian \& analisis di bidang pendidikan. Retrieved from https://books.google.co.id/books?i $\mathrm{d}=805$ _tQEACAAJ

Widarti, A. (2013). Kemampuan koneksi matematis dalam menyelesaikan masalah kontekstual ditinjau dari kemampuan matematis siswa. Skripsi. STKIP PGRI Jombang.

Yazgan, Y. (2015). Sixth graders and non-routine problems: which strategies are decisive for success. Educational Research and Reviews, 10(13), 1807-1816.

Zakaria, E., Ibrahim, \& Maat, S. M. (2010). Analysis of students' error in learning of quadratic equations. International Education Studies, 3(3). 